\title{
Peran Warmth, Gregariousness, Assertiveness, Activity Level, Excitement Seeking dan Positive Emotions dalam Merefleksikan Kepribadian Extraversion
}

\section{The Role of Warmth, Gregariousness, Assertiveness, Activity Level, Excitement Seeking and Positive Emotions in Reflecting Extraversion Personality}

\author{
Pipih Muhopilah, Fatwa Tentama, Yuzarion \\ Fakultas Psikologi Universitas Ahmad Dahlan, Yogyakarta, Indonesia
}

\begin{abstract}
Extraversion personality is one of the personality dimensions in the big five pesonality. The extraversion personality is reflected in six aspects, namely warmth, gregariousness, assertiveness, activity level, excitement seeking and positive emotions. The purpose of this study was to examine the construct validity and construct reliability on the extraversion personality scale as well as to examine the aspects and indicators that reflect the construct of extraversion personality. The population in this study were all students of class VIII at schools X, Y, Z which are state junior high schools in Yogyakarta with a total of 524 students. The sample in this study is 185 students. The sampling technique uses cluster random sampling. The data collection method used extraversion personality scale. Research data were analyzed using Structural Equation Modeling (SEM) through the SmartPLS 3.2.8 program. Based on the results of the data analysis, the aspects and indicators that reflect the extraversion personality construct are valid and reliable. The most dominant aspect that reflects extraversion personality is the activity level with a loading factor of 0,764 . Meanwhile, the weakest aspect in reflecting extraversion personality is warmth with a loading factor value of 0,424 . These results indicate that all aspects and indicators are able to reflect the extraversion personality construct. Thus, the measurement model can be accepted because the theory describes the personality construct of extraversion fit with empirical data obtained from the subject.
\end{abstract}

Keywords: Activity level, extraversion personality, warmth

\begin{abstract}
Abstrak: Kepribadian extraversion adalah salah satu dimensi kepribadian dalam big five pesonality. Kepribadian extraversion direfleksikan melalui enam aspek yaitu warmth, gregariousness, assertiveness, activity level, excitement seeking dan positive emotions. Tujuan penelitian ini adalah untuk menguji validitas konstruk dan reliabilitas konstruk pada skala kepribadian extraversion serta menguji aspek-aspek dan indikator-indikator yang dapat merefleksikan konstruk kepribadian extraversion. Populasi dalam penelitian ini adalah seluruh siswa kelas VIII pada sekolah X, Y, Z yang merupakan sekolah menengah pertama negeri di Yogyakarta dengan jumlah 524 siswa. Sampel dalam penelitian ini berjumlah 185 siswa. Teknik sampling menggunakan cluster random sampling. Metode pengumpulan data menggunakan skala kepribadian extraversion. Data penelitian dianalisis dengan Structural Equation Modeling (SEM) melalui program SmartPLS 3.2.8. Berdasarkan hasil analisis data, diperoleh hasil aspek-aspek dan indikator yang merefleksikan konstruk kepribadian extraversion dinyatakan valid dan reliabel. Aspek yang paling dominan merefleksikan kepribadian extraversion adalah activity level dengan loading factor 0,764. Sedangkan aspek yang paling lemah dalam merefleksikan kepribadian extraversion adalah warmth dengan nilai loading factor 0,424 Hasil tersebut menunjukkan bahwa semua aspek dan indikator mampu merefleksikan konstruk kepribadian extraversion. Dengan demikian, model pengukuran bisa diterima karena teori yang menggambarkan konstruk kepribadian extraversion fit dengan data empirik yang diperoleh dari subjek.
\end{abstract}

Kata kunci: Activity level, kepribadian extraversion, warmth

Korespondensi tentang artikel ini dapat dapat dialamatkan kepada Fatwa Tentama melalui e-mail: fatwa.tentama@psy.uad.ac.id 
Psikologi kepribadian memandang trait sebagai pola pikiran yang terintegrasi, perasaan-perasaan dan perilaku yang berbeda antara individu, tetapi dapat muncul secara stabil pada seseorang di situasi dan waktu yang berbeda (Zou, Su, Qi, Zheng, \& Wang, 2018; Pang, dkk 2016). McCrae dan Costa (2003) mengembangkan lima faktor kepribadian (big five personality) yang terdiri dari extraversion, agreeableness, conscientiousness, neuroticism, dan openness. Salah satu dimensi kepribadian yang penting untuk diteliti adalah extraversion (Lei, Zhao, \& Chen, 2013).

Extraversion merupakan perilaku yang digambarkan dengan suka bergaul, banyak bicara, ramah, banyak melakukan interaksi interpersonal (Piedmont, 1998). Individu dengan extraversion yang tinggi cenderung ekstrovert, outgoing, energic dan banyak berbicara (Boang \& Tilopolous, 2011). Dalam berhubungan dengan lingkungan sosial, extraversion digambarkan sebagai individu yang antusias, bersemangat dan percaya diri dalam menjalani berbagai pengalaman sosial (John \& Srivastava, 1999; Rolland, 2002). McCrae dan Costa (2003) berpendapat bahwa kepribadian extraversion direpresentasikan dengan mudah bergaul, aktif, dan berorientasi pada orang lain. Individu dengan extraversi tinggi juga cenderung asertif (Suslow, Lindner, Kugel, Egloff, \& Schmukle, 2014).

Extraversion yang tinggi berhubungan dengan tingginya minat untuk berafiliasi dan membangun keakraban (Sacco \& Brown, 2018), serta kompetitif (Fong, Zhao, \& Smillie, 2021). Individu dengan extraversion tinggi suka mencari kesenangan, namun ketika pencarian kesenangan tersebut dilakukan dengan mengabaikan perasaan orang lain maka dapat menimbulkan berbagai perilaku negatif seperti bullying (Dåderman \& Ragnestål-Impola, 2019). Dalam memimpin, individu dengan extraversi tinggi dapat menjadi pemimpin yang efektif ketika memiliki anggota yang pasif, namun kurang efektif ketika memiliki anggota yang proaktif karena individu dengan extraversi tinggi kurang bisa menerima sikap proaktif (Oshio, Taku, Hirano, \& Saeed, 2018). Extraversi dalam tingkat moderat berhubungan dengan resiliensi dan faktor protektif untuk perasaan tertekan (Wardenaar, Conradi, Bos, \& de Jonge, 2014; Boudouda \& Gana, 2020; Backmann, Weiss, Schippers,
\& Hoegl,2019). Remaja dengan extraversion tinggi menunjukkan sikap yang lebih proaktif (Wang, Ang, Jiang, \& Wu, 2019) serta mudah untuk melakukan penyesuaian sosial (Shu, McAbee, \& Ayman, 2017).

Mc Care dan Costa (2003) menyebutkan bahwa ada enam aspek yang membangun kepribadian extraversion, yaitu: 1) warmth (kehangatan atau ketertarikan): memiliki gaya interaksi yang ramah, bersahabat, dan memiliki keterikatan dengan orang lain; 2) gregariousness (keinginan untuk bersama orang lain): suka berteman, suka berada di keramaian, suka berbicara, tidak memiliki banyak kekhawatiran, menyukai stimuli sosial; 3) assertiveness (ketegasan): memiliki kemampuan memimpin, mudah menerima perubahan, berpikir dengan caranya sendiri, mampu mengekspresikan perasaan dan keinginannya; 4) activity level (aktivitas): menyukai kesibukan, bertindak dengan penuh semangat, gesit, menikmati tugas yang diberikan, berbicara dengan cepat, energik dan kuat; 5) excitement seeking (mencari kesenangan): menyukai lingkungan yang menantang, mencari kesenangan, suka pada hal-hal yang beresiko; 6) positive emotions: suka mencari kegembiraan, bersemangat, kehidupan yang menggairahkan. Berdasarkan aspek-aspek kepribadian extraversion, dapat dibentuk kerangka konseptual kepribadian extraversion yang terlihat pada Gambar 1. Hipotesis dalam penelitian ini adalah aspek-aspek kepribadian extraversion yaitu warmth, gregariousness, assertiveness, activity level, excitement seeking, dan positive emotions secara bersama-sama mampu merefleksikan konstruk kepribadian extraversion.

Salah satu pendekatan yang digunakan dalam menguji konstruk suatu alat ukur adalah Confirmatory Factor Analysis (CFA), yang merupakan salah satu dari pendekatan utama di dalam analisis faktor. Pada Confirmatory Factor Analysis (CFA) ini faktor-faktor yang terbentuk berasal dari teori bukan dari hasil statistik Exploratory Factor Analysis (EFA) dan digunakan untuk membuktikan (konfirmasi) sebuah teori pengukuran. Confirmatory Factor Analysis (CFA) dapat digunakan untuk menguji aspek suatu konstruk. Pengujian ini digunakan untuk melakukan pengukuran model kepribadian extraversion sehingga dapat menggambarkan aspek dan indikator perilaku dalam merefleksikan variabel laten kepri- 


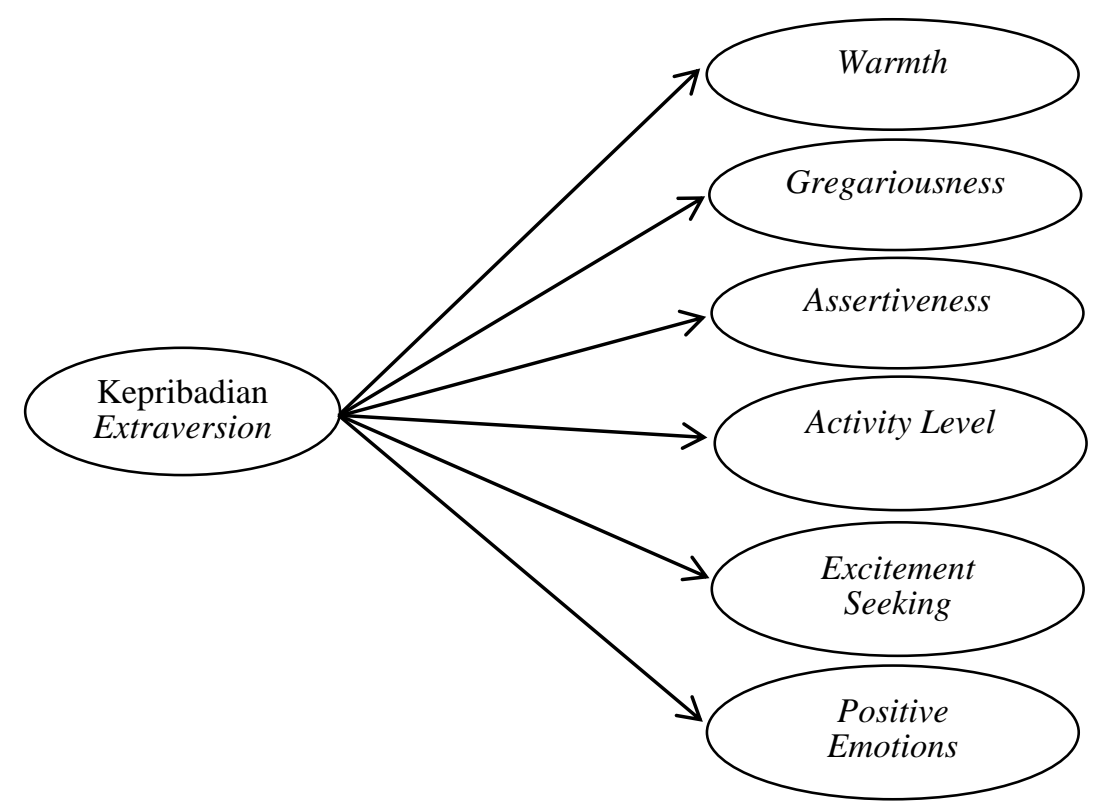

Gambar 1. Model Konseptual Kepribadian Extraversion

badian extraversion dengan melihat loading factor dari tiap aspek yang membentuk konstruk dari kepribadian extraversion. Confirmatory Factor Analysis (CFA) juga digunakan untuk menguji validitas konstruk dan reliabilitas konstruk dari indikatorindikator (item-item) pembentuk konstruk laten (Ghozali \& Latan, 2012).

Confirmatory Factor Analysis (CFA) yang digunakan dalam penelitian ini adalah second order Confirmatory Factor Analysis ( $2^{\text {nd }}$ Order CFA), yaitu model pengukuran yang terdiri dari dua tingkat. Tingkat pertama analisis dilakukan dari aspek-aspek ke indikator-indikatornya dan kedua analisis dilakukan dari konstruk laten ke aspekaspeknya (Latan, 2012).Berdasarkan uraian yang telah dipaparkan di atas menunjukkan bahwa kepribadian extraversion adalah salah satu kepribadian yang penting untuk dipahami, maka diperlukan skala yang valid dan reliabel untuk dapat mengukur kepribadian extraversion. Maka rumusan masalah dalam penelitian ini adalah: 1) apakah skala kepribadian extraversion valid dan reliabel?; 2) apakah aspek warmth, gregariousness, assertiveness, activity level, excitement seeking dan positive emotions secara bersama-sama mampu merefleksikan konstruk kepribadian extraversion? Tujuan penelitian ini adalah untuk menganalisis validitas dan reliabilitas konstruk kepribadian extraversion serta untuk menguji aspek-aspek dan indikator-indikator yang merefleksikan konstruk kepribadian extraversion.

\section{Metode}

\section{Populasi, Sampel dan Teknik Sampling}

Subjek penelitian ini adalah siswa kelas VIII pada sekolah menengah pertama negeri X, Y, Z di Yogyakarta. Populasi penelitian ini berjumlah 524 siswa, dengan sampel berjumlah 185 siswa yang terdiri dari 98 laki-laki dan 87 perempuan dengan rentang usia 13-16 tahun (rata-rata $=14$ tahun) teknik sampling menggunakan cluster random sampling. Perizinan penelitian terhadap subjek penelitian oleh pihak sekolah melalui guru Bimbingan Konseling (BK) selaku pihak yang bertanggung jawab sebelum dilakukannya penelitian.

\section{Pengumpulan Data}

Kepribadian extraversion dalam penelitian ini diukur dengan skala kepribadian extraversion dengan model penskalaan semantic diferensial. Skala penelitian mengacu pada aspek-aspek kepribadian extraversion menurut McCare dan Costa (2003), aspek tersebut yaitu, warmth, gregariousness, assertiveness, activity level, excitement seeking, dan possitive emotions. Contoh aitem pada skala kepribadian 
Tabel 1. Contoh Aitem pada Skala Kepribadian Extraversion

\begin{tabular}{|c|c|c|c|c|c|}
\hline \multicolumn{6}{|c|}{ Saat bertemu dengan orang yang baru dikenal, saya..... } \\
\hline Sulit akrab & 1 & 2 & 3 & 4 & Mudah akrab \\
\hline Takut & 1 & 2 & 3 & 4 & Tenang \\
\hline Merasa malas & 1 & 2 & 3 & 4 & $\begin{array}{c}\text { Merasa } \\
\text { bersemangat }\end{array}$ \\
\hline \multicolumn{6}{|c|}{ Dalam bergaul dengan teman, saya biasanya.... } \\
\hline Pasif & 1 & 2 & 3 & 4 & Aktif \\
\hline Kaku & 1 & 2 & 3 & 4 & Fleksibel \\
\hline $\begin{array}{l}\text { Manutan (mengikuti } \\
\text { pendapat teman) }\end{array}$ & 1 & 2 & 3 & 4 & Berani berpendapat \\
\hline \multicolumn{6}{|c|}{ Ketika banyak kegiatan saya merasa.... } \\
\hline Kesal & 1 & 2 & 3 & 4 & Senang \\
\hline Malas & 1 & 2 & 3 & 4 & Bersemangat \\
\hline Putus asa & 1 & 2 & 3 & 4 & Tertantang \\
\hline \multicolumn{6}{|c|}{ Saat berbicara dengan teman sekolah, saya..... } \\
\hline Malas & 1 & 2 & 3 & 4 & Antusias \\
\hline $\begin{array}{c}\text { Banyak } \\
\text { mendengarkan }\end{array}$ & 1 & 2 & 3 & 4 & Banyak bertanya \\
\hline Tertutup & 1 & 2 & 3 & 4 & Terbuka \\
\hline Malas & 1 & 2 & 3 & 4 & Antusias \\
\hline \multicolumn{6}{|c|}{ Kegiatan yang saya lakukan...... } \\
\hline Monoton & 1 & 2 & 3 & 4 & Beragam \\
\hline Mudah & 1 & 2 & 3 & 4 & Rumit \\
\hline Aman & 1 & 2 & 3 & 4 & Beresiko \\
\hline \multicolumn{6}{|c|}{ Saya menilai diri saya sebagai seseorang yang....... } \\
\hline $\begin{array}{l}\text { Lebih sering merasa } \\
\text { sedih }\end{array}$ & 1 & 2 & 3 & 4 & $\begin{array}{l}\text { Lebih sering } \\
\text { merasa bahagia }\end{array}$ \\
\hline Senang menyendiri & 1 & 2 & 3 & 4 & $\begin{array}{l}\text { Senang bersama- } \\
\text { sama orang lain }\end{array}$ \\
\hline Tidak berharga & 1 & 2 & 3 & 4 & Berharga \\
\hline
\end{tabular}

extraversion dapat dilihat pada Tabel 1. Adapun blueprint yang dijadikan acuan dalam penyusunan skala kepribadian extraversion dapat dilihat pada Tabel 2.

Validitas konstruk dan reliabilitas konstruk

Pengujian validitas konstruk serta reliabilitas konstruk dalam penelitian ini menggunakan pengujian outer model melalui program smartPLS 3.2.8. Pengujian validitas konstruk terdiri dari uji validitas konvergen dan uji validitas diskriminan. Validitas konvergen dapat dilihat dari nilai loading factor $>0,4$ (Hair, Hult, Ringle, \& Sarstedt, 2017) dan nilai Average Variance Extracted $(A V E)>0,5$ (Jogiyanto, 2011). Menurut Hair, Black, Babin, dan Anderson (2014)

Tabel 2. Blueprint Skala Kepribadian Extraversion

\begin{tabular}{|c|c|c|c|}
\hline No & Aspek & No Aitem & Jumlah Aitem \\
\hline 1 & Warmth & $1,2,3,4,5,6$ & 6 \\
\hline 2 & Gregariousness & $7,8,9,10,11,12$ & 6 \\
\hline 3 & Assertiveness & $13,14,15,16,17,18$ & 6 \\
\hline 4 & Activity Level & $19,20,21,22,23,24$ & 6 \\
\hline 5 & Excitement Seeking & $25,26,27,28,29,30$ & 6 \\
\hline 6 & Possitive Emotions & $31,32,33,34,35,36$ & 6 \\
\hline & Jumlah & & 36 \\
\hline
\end{tabular}


semakin tinggi skor loading factor maka akan semakin penting peranan loading dalam menginterpretasikan matrik faktor. Nilai loading factor $>0,4$ dan nilai Average Variance Extracted (AVE) > 0,5 dianggap telah memenuh syarat (Hair, Hult, Ringle, \& Sarstedt, 2017; Jogiyanto, 2011). Sedangkan validitas diskriminan dapat dilihat dari membandingkan akar Average Variance Extracted (AVE) antar aspek harus lebih tinggi dibandingkan korelasi dengan aspek lain (Jogiyanto, 2011).

Uji reliabilitas konstruk dilakukan untuk menunjukan konsistensi internal alat ukur yaitu dengan meilihat nilai composite reliability dan Cronbach alpha dengan nilai yang lebih tinggi maka akan menunjukan nilai konsistensi dari masing-masing aitem dalam mengukur variabel laten. Nilai composite reliability dan Cronbach alpha yang diharapkan ialah > 0,7 dan nilai 0,6 masih dapat diterima (Jogiyanto, 2011; Hair, Hult, Ringle, \& Sarstedt, 2017).

Analisis data

Data dalam penelitian ini dianalisis de- ngan menggunakan outer model dengan pendekatan second order Confirmatory Factor Analysis (2 ${ }^{\text {nd }}$ Order CFA) melalui program SmartPLS 3.2.8. Partial Least Square (PLS) adalah Structural Equation Modeling (SEM) berbasis varians yang secara simultan dapat melakukan pengujian model pengukuran untuk menguji validitas dan reliabilitas konstruk (Abdillah \& Hartono, 2015).

\section{Hasil}

Berdasarkan pengujian outer model skala kepribadian extraversion yang dilakukan dengan menggunakan program smartPLS 3.2.8 dapat dilihat hasilnya pada Gambar 2 di bawah ini.

\section{Hasil Uji Validitas Konstruk}

\section{Validitas konvergen}

Hasil uji validitas konvergen dilakukan dengan pengujian outer model yang dilihat dari nilai loading factor dan nilai Average Variance Extracted (AVE). Pengujian ini

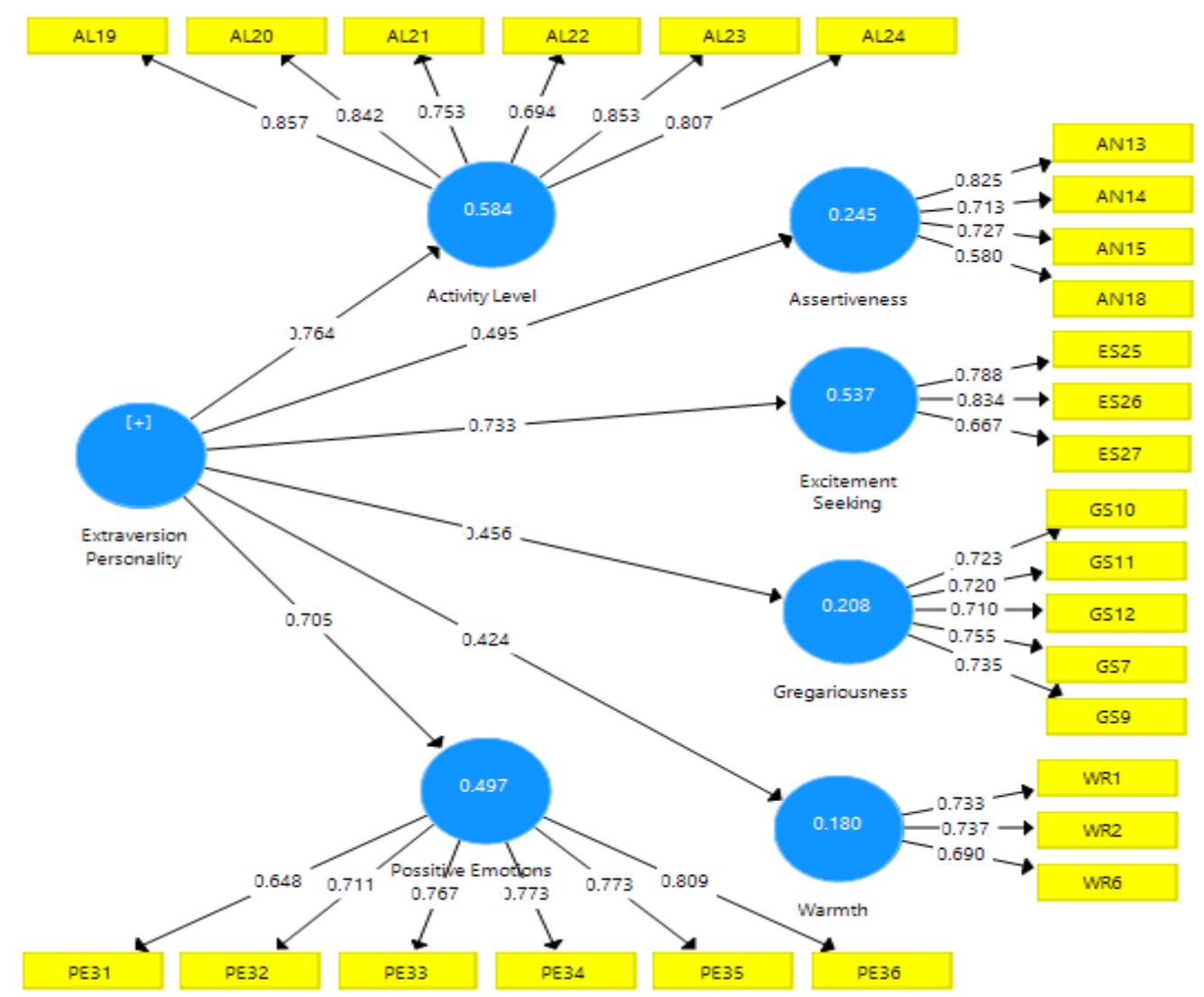

Gambar 2. Output Outer Model Skala Kepribadian Extraversion 
dilakukan dengan melihat nilai loading factor $>0,4$ dan Average Variance Extracted $(A V E)>0,5$.

Berdasarkan analisis data yang dilakukan, didapatkan bahwa nilai loading factor dari variabel ke aspek dan nilai loading factor dari aspek ke indikator-indikator memiliki nilai $>0,4$. Bobot loading factor sebesar 0,4 atau lebih dianggap memiliki validitas yang cukup kuat untuk menjelaskan konstruk laten (Hair, Hult, Ringle, \&
Sarstedt, 2017). Hasil pengujian validitas konvergen dapat dilihat pada Tabel 2 dan Tabel 3. Selanjutnya, hasil uji validitas konvergen menunjukan nilai Average Variance Extracted (AVE) $>0,5$. Nilai Average Variance Extracted (AVE) dari variabel kepribadian extraversion adalah 0,566 dan nilai Average Variance Extracted $(A V E)$ dari masing-masing aspek kepribadian extraversion dapat dilihat pada Tabel 4.

Tabel 2. Nilai Loading Factor (Variabel ke Aspek)

\begin{tabular}{lcc}
\hline \multicolumn{1}{c}{ Aspek } & Loading Factor & Keterangan \\
\hline Warmth & 0,424 & Valid \\
Gregariousness & 0,456 & Valid \\
Assertiveness & 0,495 & Valid \\
Activity Level & 0,764 & Valid \\
Excitement Seeking & 0,733 & Valid \\
Possitive Emotions & 0,705 & Valid \\
\hline
\end{tabular}

Tabel 3. Nilai Loading Factor (Aspek ke Indikator)

\begin{tabular}{ccc}
\hline Aitem & Loading Factor & Keterangan \\
\hline AL19 & 0,857 & Valid \\
AL20 & 0,842 & Valid \\
AL21 & 0,753 & Valid \\
AL22 & 0,694 & Valid \\
AL23 & 0,853 & Valid \\
AL24 & 0,807 & Valid \\
AN13 & 0,825 & Valid \\
AN14 & 0,713 & Valid \\
AN15 & 0,727 & Valid \\
AN18 & 0,580 & Valid \\
ES25 & 0,788 & Valid \\
ES26 & 0,834 & Valid \\
ES27 & 0,667 & Valid \\
GS10 & 0,723 & Valid \\
GS11 & Valid \\
GS12 & 0,720 & Valid \\
GS7 & 0,710 & Valid \\
GS9 & 0,755 & Valid \\
WR1 & 0,735 & Valid \\
WR2 & 0,733 & Valid \\
WR3 & 0,737 & Valid \\
PE31 & 0,690 & Valid \\
PE32 & 0,648 & Valid \\
PE33 & 0,711 & Valid \\
PE34 & 0,767 & Valid \\
PE35 & 0,773 & Valid \\
PE36 & 0,773 & Valid \\
\hline
\end{tabular}


Tabel 4. Nilai Average Variance Extracted (AVE) pada Aspek-Aspek Kepribadian Extraversion

\begin{tabular}{lcc}
\hline \multicolumn{1}{c}{ Aspek } & Nilai AVE & Keterangan \\
\hline Warmth & 0,519 & Valid \\
Gregariousness & 0,531 & Valid \\
Assertiveness & 0,513 & Valid \\
Activity Level & 0,645 & Valid \\
Excitement Seeking & 0,587 & Valid \\
Possitive Emotions & 0,561 & Valid \\
\hline
\end{tabular}

\section{Validitas diskriminan}

Berdasarkan hasil uji validitas diskriminan menunjukkan bahwa nilai korelasi akar Average Variance Exrtacted (AVE) pada masing masing aspek kepribadian extraversion lebih tinggi dibandingkan nilai korelasi dengan akar Average Variance Extracted (AVE) pada aspek kepribadian extraversion lain, sehingga kriteria validitas diskriminannya terpenuhi. Nilai akar dari Average Variance Extracted ( $A V E$ ) variabel kepribadian extraversion dapat dilihat pada Tabel 5.

\section{Uji reliabilitas konstruk}

Pengujian reliabilitas konstruk dilakukan dengan pengujian outer model. Reliabilitas dilihat dari nilai composite reliability dan Cronbach alpha, dengan composite reliability dapat menunjukkan nilai yang lebih akurat (Werts, Linn, \& Joreskog, 1974). Skala dianggap reliabel jika nilai composite reliability dan Cronbach alpha >
0,7 (Nunnally \& Bernstein, 1994), dan 0,6 juga masih diperbolehkan (Jogiyanto, 2011). Nilai dari composite realibility dan Cronbach alpha pada variabel kepribadian extraversion dapat dilihat pada Tabel 6.

Berdasarkan hasil pengujian reliabilitas konstruk pada Tabel 6 menunjukkan bahwa skala kepribadian extraversion memiliki reliabilitas yang baik dan memberikan makna bahwa aspek yang mengukur variabel kepribadian extraversion memenuhi kriteria unidimensional (Hair, Hult, Ringle, \& Sarstedt, 2017). Hal ini ditunjukkan oleh nilai dari composite realibility 0,796 dan Cronbach alpha 0,615. Uji validitas dan reliabilitas konstruk tersebut menghasilkan aitem-aitem atau indikator indikator yang valid dan reliabel yang mampu merefleksikan aspek kepribadian extraversion yaitu aitem pada nomor $1,2,6,7,9,10,11,12$, $13,14,15,18,19,20,21,22,23,24,25,26$, 27, 31, 32, 33, 34, 35, dan 36. Berdasarkan hasil analisis data penelitian menggunakan pengujian outer model menunjukan bahwa model pengukuran bisa diterima karena

Tabel 5. Nilai Akar Average Variance Extracted (AVE) Kepribadian Extraversion

\begin{tabular}{lcccccc}
\hline & Warmth & Gregariousness & Assertiveness & $\begin{array}{c}\text { Activity } \\
\text { Level }\end{array}$ & $\begin{array}{c}\text { Excitement } \\
\text { Seeking }\end{array}$ & $\begin{array}{c}\text { Possitive } \\
\text { Emotions }\end{array}$ \\
\hline Warmth & 0,720 & 0,467 & 0,331 & 0,399 & 0,296 & 0,433 \\
Gregariousness & 0,467 & 0,729 & 0,469 & 0,305 & 0,409 & 0,477 \\
Assertiveness & 0,331 & 0,469 & 0,717 & 0,366 & 0,414 & 0,492 \\
$\begin{array}{l}\text { Activity Level } \\
\text { Excitement }\end{array}$ & 0,399 & 0,305 & 0,366 & 0,803 & 0,460 & 0,455 \\
$\begin{array}{l}\text { Seeking } \\
\text { Possitive }\end{array}$ & 0,296 & 0,409 & 0,414 & 0,460 & 0,766 & 0,485 \\
Emotions & 0,433 & 0,477 & 0,492 & 0,455 & 0,485 & 0,749 \\
\hline
\end{tabular}

Tabel 6. Nilai Composite Realibility dan Cronbach Alpha Kepribadian Extraversion

\begin{tabular}{cccc}
\hline Variabel & Composite Realibility & Cronbach Alpha & Keterangan \\
\hline Kepribadian extraversion & 0,796 & 0,615 & Reliabel \\
\hline
\end{tabular}


semua aspek kepribadian extraversion mampu merefleksikan variabel kepribadian extraversion. Namun, penelitian ini tidak terlepas dari kekurangan, diantaranya yaitu masih terbatasnya data mengenai variasi partisipan, seperti data mengenai latar belakang budaya yang belum dikaji dalam penelitian ini.

\section{Pembahasan}

Hasil analisis validitas dan realiabilitas skala kepribadian extraversion menunjukkan bahwa aspek extraversion dan indikatorindikator yang merefleksikan konstruk kepribadian extraversion dinyatakan valid dan reliabel. Hasil tersebut menunjukkan bahwa semua aspek kepribadian extraversion dan indikator-indikator yang merefleksikan konstruk kepribadian extraversion mampu merefleksikan konstruk kepribadian exraversion. Aspek yang paling dominan dan mampu merefleksikan konstruk kepribadian extraversion adalah activity level dengan nilai loading factor 0,764 .

Activity level digambarkan dengan merasa senang dan bersemangat ketika banyak kegiatan, merasa tertantang untuk melakukan banyak kegiatan, menikmati berbagai kegiatan yang dilakukan serta merasa waktu begitu cepat ketika mengikuti banyak kegiatan. Aspek yang paling lemah dan mampu merefleksikan kepribadian extraversion adalah warmth dengan nilai loading factor 0,424. Warmth ditunjukkan dengan mudal bergaul dengan orang lain, suka tersenyum dan menyapa, banyak bertanya dan menunjukkan antusiasme saat berbicara dengan orang lain, serta bersikap terbuka dengan siapa saja.

Hasil penelitian sebelumnya mengenai konstruk kepribadian extraversion yang relevan dengan penelitian ini dan juga memaparkan validitas dan reliabilitas skala kepribadian extraversion diantaranya yaitu penelitian dari Zafar, Hashim, dan Halim (2019). Pada penelitian tersebut, kepribadian extraversion diukur melalui skala five personality traits yang dikembangkan oleh Goldberg (1992) dan dianalisis melalui program Amos. Hasil penelitian ini menunjukkan bahwa skala kepribadian extraversion telah memenuhi syarat reliabilitas dengan nilai composite reliability 0,766 . Kemudian Zafar, Hashim, Halim, dan Attique (2020) kembali melakukan penelitian mengenai kepribadian extraversion, dengan menggunakan skala personality traits yang disusun oleh Goldberg dan Stycker (2002) dengan proses analisisnya menggunakan program Amos. Hasil penelitian tersebut juga menunjukkan bahwa skala kepribadian extraversion telah memenuhi syarat reliabilitas dengan nilai composite reliability 0,714 .

Hasil penelitian lain yang dilakukan oleh Dedeoglu, Okumus, Yi, dan Jin (2019) yang mengukur kepribadian extraversion menggunakan skala Five-Factor personality traits yang dikembangkan oleh Gosling, Rentfrow, dan Swann (2003). Hasil penelitian tersebut menunjukkan bahwa skala kepribadian extraversion telah memenuhi syarat reliabilitas dengan nilai composite reliability 0,780 . Penelitian lainnya dilakukan oleh Rahman (2017) dengan analisis menggunakan PLS-SEM. Hasil penelitian tersebut menunjukkan skala kepribadian extraversion telah memenuhi syarat reliabilitas dengan nilai composite reliability 0,793 .

Hasil-hasil penelitian tersebut bila dibandingkan dengan penelitan ini menunjukkan bahwa hasil penelitian ini juga dapat dijadikan instrumen untuk mengukur kepribadian extraversion, karena hasil analisis reliabilitas menunjukkan bahwa skala dalam penelitian ini memiliki nilai reliabilitas yang lebih tinggi dengan nilai composite reliability 0,796 dan Cronbach alpha 0,615 termasuk dalam kategori baik (Nunnally \& Bernstein, 1994).

Hasil penelitian ini diharapkan dapat memberikan gambaran tentang validitas dan reliabilitas konstruk skala kepribadian extraversion khususnya dalam mengungkap kepribadian extraversion pada konteks siswa sekolah menengah pertama di Yogyakarta sehingga dapat digunakan dalam pengambilan data penelitian dan menjadi acuan dalam penelitian selanjutnya yang terkait dengan kepribadian exraversion.

\section{Simpulan}

Berdasarkan hasil analisis dan pembahasan dapat diperoleh kesimpulan bahwa: 1) skala kepribadian extraversion memenuhi syarat validitas dan reliabilitas; 2) semua aspek dan indikator dapat merefleksikan konstruk kepribadian extraversion, yaitu warmth, gregariousness, assertiveness, activity level, excitement seeking dan positive emotions. Aspek yang paling 
dominan dalam merefleksikan kepribadian extraversion adalah activity level, sedangkan aspek yang memiliki peran paling lemah dalam merefleksikan variabel kepribadian extraversion adalah warmth. Pada penelitian ini terbentuk model pengukuran skala kepribadian extraversion yang sesuai dengan data empirik yang diperoleh dari subjek.

\section{Saran}

Bagi penelitian selanjutnya, sebaiknya dapat meneliti kepribadian extraversion dengan dikaitkan dengan variabel lainnya, sehingga dapat diketahui pengaruh kepribadian extraversion pada berbagai aspek kehidupan manusia.

\section{Acknowledgement}

Penulis mengucapkan terimakasih kepada Kementerian Riset, Teknologi dan Pendidikan Tinggi Republik Indonesia yang telah menyediakan dukungan pendanaan bagi penelitian ini.

\section{Daftar Pustaka}

Abdillah, W., \& Hartono, J. (2015). Partial Least Square (PLS): Alternatif Structural Equation Modeling (SEM) dalam penelitian bisnis. Penerbit Andi.

Backmann, J., Weiss, M., Schippers, M. C., \& Hoegl, M. (2019). Personality factors, student resiliency, and the moderating role of achievement values in study progress. Learning and Individual Differences, 72, 39-48. https://doi.org/10.1016/j.lindif.2019.0 4.004

Boang, S., \& Tilopolous, N. (2011). Personality and individual differences: Theory, assessment, and aplication. Nova Science Publisher.

Boudouda, N. E., \& Gana, K. (2020). Neuroticism, conscientiousness and extraversion interact to predict depression: A confirmation in a nonWestern culture. Personality and Individual Differences, 167, 110219. https://doi.org/10.1016/j.paid.2020.11 0219

Dåderman, A. M., \& Ragnestål-Impola, C. (2019). Workplace bullies, not their victims, score high on the dark triad and extraversion, and low on agreeableness and honestyhumility. Heliyon, 5(10), 1-9. https://doi.org/10.1016/j.heliyon.2019. e02609

Dedeoglu, B. B., Okumus, F., Yi, X., \& Jin, W. (2019). Do tourists' personality traits moderate the relationship between social media content sharing and destination involvement? Journal of Travel \& Tourism Marketing, 36(5), 612-626.

https://doi.org/10.1080/10548408.201 9.1604294

Fong, M., Zhao, K., \& Smillie, L. D. (2021). Personality and competitiveness: Extraversion, agreeableness, and their aspects, predict self-reported competitiveness and competitive bidding in experimental auctions. Personality and Individual Differences, 169, 109907. https://doi.org/10.1016/j.paid.2020.10 9907

Ghozali, I., \& Latan, H. (2012). Partial least squares: Konsep, metode dan aplikasi menggunakan program warPLS 2.0 untuk penelitian empiris. Badan Penerbit Universitas Diponegoro.

Goldberg, L. R. (1992). The development of markers for the big-five factor structure. Psychological Assessment, 4(1), 26-42. https://psycnet.apa.org/doi/10.1037/10 40-3590.4.1.26

Goldberg, L. R., \& Strycker, L. A. (2002). Personality traits and eating habits: The assessment of food preferences in a large community sample. Personality and individual differences, 32(1), 49-65. https://doi.org/10.1016/S01918869(01)00005-8

Gosling, S. D., Rentfrow, P. J., \& Swann Jr, W. B. (2003). A very brief measure of the big-five personality domains. 
Journal of Research in Personality, 37(6), $\quad$ 504-528. https://doi.org/10.1016/S00926566(03)00046-1

Hair Jr, J. F., Hult, G. T. M., Ringle, C., \& Sarstedt, M. (2017). A primer on partial least squares Structural Equation Modeling (PLS-SEM). Sage Publications.

Jogiyanto, H. M. (2011). Konsep dan aplikasi structural equation modeling berbasis varian dalam penelitian bisnis. UPP STIM YKPN.

John, O. P., \& Srivastava, S. (1999). The big five trait taxonomy: History, measurement, and theoritical perspectives. The Guilford Press.

Latan, H. (2012). Structural equation modeling: Konsep dan aplikasi menggunakan program Lisrel 8.80. Bandung: Alfabeta.

Lei, X., Zhao, Z., \& Chen, H. (2013). Extraversion is encoded by scale-free dynamics of default mode network. NeuroImage, $74, \quad 52-57$. https://doi.org/10.1016/j.neuroimage.2 013.02.020

McCrae, R. R., \& Costa, P. T. (2003). Personality in adulthood: A five-factor theory perspective. Guilford Press.

Nunnally, J. C., \& Bernstein, I. H. (1994). Psychometric theory. Psychometric Theory, 3, 248-292.

Oshio, A., Taku, K., Hirano, M., \& Saeed, G. (2018). Resilience and big five personality traits: A metaanalysis. Personality and Individual Differences, 127, 54-60. https://doi.org/10.1016/j.paid.2018.01. 048

Pang, Y., Cui, Q., Wang, Y., Chen, Y., Wang, X., Han, S., Zhang, Z., Lu, G., \& Chen, H. (2016). Extraversion and neuroticism related to the resting-state effective connectivity of amygdala. Scientific reports, 6(1), 1-9. https://doi.org/10.1038/srep35484

Piedmont, R. L. (1998). The revised neo personality inventory: Clinican and research aplications. New York: Springer.

Rahman, M. S. (2017). Does personality matter when we are sick? An empirical study of the role of personality traits and health emotion in healthcare technology adoption decision. In Proceedings of the 50th Hawaii International Conference on System Sciences, 3357-3366. https://doi.org/10.24251/HICSS.2017. 407

Rolland, J. P. (2002). Cross-cultural generalizability of the five-factor model of personality. In Allik, J., \& $\mathrm{McCrae}$, R.R. The five factor model of personality across cultures (pp.728). New York: Springer.

Sacco, D. F., \& Brown, M. (2018). Preferences for facially communicated big five personality traits and their relation to self-reported big five personality. Personality and Individual Differences, 134(1), 195200.

https://doi.org/10.1016/j.paid.2018.06. 024

Shu, F., McAbee, S. T., \& Ayman, R. (2017). The HEXACO personality traits, cultural intelligence, and international student adjustment. Personality and Individual Differences, 106, 21-25. https://doi.org/10.1016/j.paid.2016.10. 024

Suslow, T., Lindner, C., Kugel, H., Egloff, B., \& Schmukle, S. C. (2014). Using implicit association tests for the assessment of implicit personality self-concepts of extraversion and neuroticism in schizophrenia. Psychiatry Research, 218(3), 272-276. https://doi.org/10.1016/j.psychres.201 4.04.023

Wang, Y., Ang, C., Jiang, Z., \& Wu, C. H. (2019). The role of trait extraversion in shaping proactive behavior: A multilevel examination of the impact of high-activated positive affect. Personality and Individual Differences, 136(1), 107-112. https://doi.org/10.1016/j.paid.2018.01. 035 
Wardenaar, K. J., Conradi, H. J., Bos, E. H., \& de Jonge, P. (2014). Personality modulates the efficacy of treatment in patients with major depressive disorder. The Journal of Clinical Psychiatry, 75, e916-e923. https://doi.org/10.4088/JCP.13m08855

Werts, C. E., Linn, R. L., \& Joreskog, K. G. (1974). Intraclass reliability estimates: Testing structural assumptions. Educational and Psychological Measurement, 34, 25-33. https://doi.org/10.1177\%2F001316447 403400104

Zafar, M. Z., Hashim, N. A., \& Halim, F. (2019). Nutritional menu of eatery make consumer able to select healthy food. Pertanika Journal of Social Sciences \& Humanities, 27(4), 23512365. https://www.researchgate.net/publicati on/346934549_Nutritional_Menu_of_ Eatery_Make_Consumer_Äble_to_Sel ect_Healthy_Food

Zafar, M. Z., Hashim, N. A., Halim, F. B., \& Attique, S. (2020). Factors affecting on healthy package food selection; The impact of personality traits. Abasyn Journal of Social Sciences, 13(1),

169-193. https://doi.org/10.34091/AJSS.13.1.13

Zou, L., Su, L., Qi, R., Zheng, S., \& Wang, L. (2018). Relationship between extraversion personality and gray matter volume and functional connectivity density in healthy young adults: An fMRI study. Psychiatry Research: Neuroimaging, 281, 19-23. https://doi.org/10.1016/j.pscychresns. 2018.08.018 